\title{
Marta SZMAGIER
}

m.szmagier@gmail.com

\section{WPEYW INTERNETU NA POLSKĄ \\ GOSPODARKE - WYBRANE ASPEKTY}

ABSTRACT Internet impact on the economy and the Polish cause - selected issues

The Internet changes our lives every day and we cannot deny that it has influence on the economy. But not all countries had the same opportunities. The United States of America, Sweden and the Republic of Korea gained access to the Internet earlier than Poland or the Czech Republic. This article shows differences in various areas of the internet economy between these states and emphasizes how important are innovations and new technologies in its evolution. It also points out that society plays a decisive role in economic changes.

KEYWORDS Poland, Internet, technology, economy, innovation

\section{WSTĘP}

Elektryczność - dzisiaj trudno wyobrazić sobie, jak świat wyglądałby bez niej. Ten wynalazek stanowił przełomowy moment w dziejach ludzkości, chociaż początkowo nie dostrzegano jego wielkiej wagi. Czy wprowadzenie Internetu w życie codzienne będzie uważane za podobne wydarzenie w przeciągu kilku lub kilkunastu lat? Czy dzięki niemu świat wchodzi w nową erę? Jaki wpływ wywiera on na stan polskiej gospodarki, a jaki na stan w innych państwach? Odpowiedziom na powyższe pytania powinny przyjrzeć się osoby, w rękach których leży polityka gospodarcza naszego państwa, zaś szczegółowe analizy w tej dziedzinie powinny stać się podporą w podejmowaniu strategicznych decyzji.

Mater artium necessitas - ta sentencja sprawdza się także w przypadku stworzenia Internetu, którego początki sięgają końca lat sześćdziesiątych XX w. Kolejny raz to Stany Zjednoczone okazały się pionierem w dziedzinie innowacji. Departament 
Obrony USA zlecił agencji ARPA (Advanced Research Project Agency) przeprowadzenie projektu badawczego mającego na celu wynalezienie sieci komunikacyjnej dla wojska ${ }^{1}$. Miała być ona przydatna w razie wojny atomowej. Dzięki swej przeszłości m.in. Stany Zjednoczone Ameryki, Korea Południowa i Szwecja posiadały ułatwiony dostęp do łączy internetowych i ich rozwoju. Członkowie Układu Warszawskiego już na wstępie znaleźli się w trudniejszej sytuacji.

Pierwsze działania związane z Internetem na terenie naszego państwa odbywały się jeszcze podczas zimnej wojny, ale dopiero po zniesieniu żelaznej kurtyny, wraz z transformacją systemową, nastąpił ich dynamiczny postęp. Za początek, zarówno w Polsce, jak i w całej Europie Wschodniej, możemy przyjąć datę 20 listopada 1990 r., kiedy to za pośrednictwem krakowskiego komputera odebrano pierwszą wiadomość elektroniczną ${ }^{2}$.

Internetowi i nowym technologiom zawdzięczamy możliwość szybszego pokonywania barier dzielących nas z bardziej rozwiniętymi państwami. Wiele wskazuje na to, że jego wpływ na światową gospodarkę wciąż będzie rosnąć. Świadczyć może o tym chociażby stale wzrastająca liczba stałych użytkowników Internetu. W Polsce w marcu 2012 r. osiągnęła ona 23 miliony, co stanowiło $62 \%$ wszystkich obywateli ${ }^{3}$. Internet pozwolił na liczne udoskonalenia na poziomie gospodarstwa domowego, przedsiębiorstwa oraz państwa.

\section{INFORMACJA I KOMUNIKACJA}

Oddziaływanie Internetu można zauważyć w różnych działach gospodarki - zarówno tych zupełnie nowych, powstałych w wyniku jego rozwoju, jak i tych, które istniały wcześniej, a zostały przez jego wprowadzenie usprawnione i unowocześnione $e^{4}$. Według danych przedstawionych przez międzynarodową firmę Deloitte, gospodarka internetowa stanowiła w 2010 r. 4,8\% PKB, co wyraża się sumą 68 mld PLN. Kwota ta sięga prawie dwukrotności wpływów podatkowych od osób fizycznych z tego samo rokus.

Największą wartość z dziedzin gospodarki związanych z siecią tworzy „informacja i komunikacja" - 28\%, co stanowiło 16,7 mld PLN w 2010 r. Z badań przeprowadzonych przez zespół Uniwersytetu Michigan wynika, że średni czas wyszukania wiado-

E. Czapiewski, J. Tyszkiewicz, Historia Powszechna. Wiek XX, Warszawa 2010, s. 924-925.

A. Malik, Prawdziwy poczatek Internetu w Polsce - sensacyjne odkrycie, 7 V 2011, [online] http:// www.komputerswiat.pl/nowosci/wydarzenia/2011/40/prawdziwy-poczatek-internetu-w-polsce-nieznany-fakt.aspx, 30 VII 2012.

3 European Union Internet Users, Internet World Stats Usage and Population Statistics, 31 III 2012, [online] http://www.internetworldstats.com/europa.htm\#pl, 1 VIII 2012.

4 Polska Internetowa. Jak Internet dokonuje transformacji polskiej gospodarki, The Boston Consulting Group, V 2011, s. 25, [online] http://polskainternetowa.pl/pdf/raport_BCG_polska_internetowa. pdf, 1 VIII 2012.

5 Wptyw przyspieszonego rozwoju szerokopasmowego dostępu do Internetu na polska gospodarke - raport, Deloitte, Warszawa 2012, s. 15, [online] http://www.deloitte.com/assets/Dcom-Poland/Local\%20 Assets/Documents/Raporty,\%20badania,\%20rankingi/pl_szerokopasmowy_internet_raport_lipiec_2012.pdf, 2 VIII 2012. 
mości w tradycyjny sposób zabiera 22 minuty, tymczasem przez Internet - tylko 7. Przyśpieszenie tego procesu pomaga zaoszczędzić czas i pieniądze ${ }^{6}$. Nic więc dziwnego, że najpopularniejszą oferowaną usługą jest WWW (World Wide Web), dzięki której sieć w błyskawicznym tempie nabrała znaczenia powszechnego medium komunikacyjnego. Rzeczy zamieszczane za pomocą WWW mają różny charakter: to tekst, grafika, obraz, muzyka czy film wideo. W każdej chwili mogą być one aktualizowane, poszerzane, kasowane, zawężane?.

Internet przyniósł liczne zmiany w gospodarstwach domowych. Powszechność informacji stworzyła korzyści dla pojedynczych konsumentów, umożliwiając im wybór produktów o niższych cenach, co pozwala na oszczędności. Internet zyskał miano „nowego medium”, za pośrednictwem którego użytkownicy mogą porozumiewać się, co odróżnia go od tradycyjnych środków masowego przekazu - telewizji, radia czy prasy. Jednak mimo tego, że czasopisma zamieszczają artykuły na swoich portalach, w dalszym ciągu część z nas woli wziąć do ręki papierową gazetę niż przeczytać to samo na ekranie laptopa ${ }^{8}$.

Znacznie częściej przesyłamy dokumenty oraz informacje za pomocą poczty elektronicznej niż tradycyjnej. Jedynym warunkiem, aby z niej korzystać, jest posiadanie konta na serwerze pocztowym. To czyni z niej najszybszą i najtańszą formę łączności użytkowników Internetu. Jednak kryje się tu wiele pułapek, takich jak chociażby spam, czyli przesyłane w niezmienionej formie do wielu osób niechciane wiadomości elektroniczne o charakterze reklamowym (tzw. Unsolicited Commercial Email) lub zawierające apele organizacji społecznych czy charytatywnych i prośby o pomoc (tzw. Unsolicited Bulk Email).

Niebezpiecznym zjawiskiem związanym z informacją jest jej nadmiar, prowadzący do powstania tzw. śmietniska komunikacji'. Jednym z jego przykładów może być popularna Wikipedia. Powszechne jest jej edytowanie dla żartu, co niejednokrotnie wprowadziło użytkowników w błąd ${ }^{10}$. Przeładowanie informacyjne (ang. information overload) jest przyczyną wzrastającej niestabilności i ciągle zmniejszającej się zdolności kontrolowania oraz przewidywania. Osoby, które chcą posiadać rzetelną i sprawdzoną informację, są zmuszone rozważyć większą liczbę możliwości niż w rzeczywistości. Na pogorszenie tego stanu rzeczy wpływa także data smog, czyli rozszerzające się - dzięki łatwości publikacji - informacje o niskiej jakości, prowadzące do niepokojów oraz niebezpiecznych błędnych opinii, oddziałujących na gospodarkę ${ }^{11}$.

6 M. Niedźwiedziński, Globalny handel elektroniczny, Warszawa 2004, s. 19.

7 J. Pawłowska-Mielech, Rola i znaczenie Internetu w komunikacji spotecznej, II 2006, [online] http:// www.sceno.edu.pl/konferencja/1_5.pdf, 28 IX 2012.

8 A. Brzozowski, Gazety upadaja, bo dziennikarze wybrali internet?, 30 XII 2011, [online] http://cyfropolis.blogspot.com/2012/01/gazety-upadaja-dziennikarze-wybrali.html\#.UGmKH66xeW4, 28 IX 2012.

9 M. Karciarz, M. Dutko, Informacja w Internecie, Warszawa 2010, s. 8-9.

10 Tamże, s. 21-29.

11 F. Heylighen, Complexity and Information Overload in Society: why increasing efficiency leads to decreasing control, 12 IV 2002, [online] http://pespmc1.vub.ac.be/Papers/Info-Overload.pdf, 29 IX 2012 . 
Zmodernizowany przepływ informacji ma kluczowe znaczenie dla funkcjonowania przedsiębiorstw. Zmusza firmy do nieustannego przygotowywania nowych strategii. Internet nie tylko zmodernizował działanie firm radiowych, telewizyjnych czy gazet, ale także sam stał się, jak już wcześniej wspomniano, jednym z mass mediów. Jednak nie wszyscy zgadzają się z takim założeniem ze względu na opcje, które były w tej branży dotąd niespotykane - takie jak możliwa wymiana zdań na forach czy pod artykułami umieszczonymi na portalach internetowych. Niepokojącymi zjawiskami związanymi z przedstawianym tematem jest zanikanie papierowych czasopism oraz malejąca liczba zatrudnienia prawdziwych dziennikarzy w różnych redakcjach, o czym alarmuje się od kilku lat.

Przedstawiony powyżej wpływ na dwóch poziomach odciska piętno na gospodarce całego państwa, która stanowi system naczyń połączonych ${ }^{12}$. Asymetria informacji w niektórych przedsiębiorstwach była jedną z przyczyn kryzysu finansowego w Stanach Zjednoczonych w 2007 r., który pociągnął za sobą kolejne gałęzie ekonomiczne oraz inne państwa. Nieustannie wprowadza się poprawki w przesyłaniu danych w publicznej administracji, co ma ułatwić obywatelom spełnianie takich obowiązków, jak płacenie podatków - ale o tym w dalszej części artykułu.

\section{FINANSE I BANKOWOŚĆ}

Branżą, która stanowi 20\% uzyskanego PKB za pomocą Internetu, jest „Działalność finansowa i ubezpieczeniowa". Gospodarstwa domowe odczuwają zmiany w tym obszarze. Warto zwrócić uwagę na system transakcji internetowych, który zyskał zaufanie Polaków - około $20 \%$ naszych obywateli korzysta z tej formy zarządzania swoimi finansami ${ }^{13}$. Jednak zakładając konto elektroniczne, każdy powinien być świadomy możliwych niebezpieczeństw. Banki dbają o oszczędności, zarówno chroniąc swoje witryny protokołem SSL, uniemożliwiającym przechwyt danych, jak i stosując dodatkowe zabezpieczenia operacji: przesyłając jednorazowe kody za pomocą wiadomości SMS. Najczęściej zagrożenie stwarza sam użytkownik, nieposiadający odpowiedniego zabezpieczenia antywirusowego komputera. Korzystanie z kafejek internetowych też wydaje się nieroztropne, z uwagi na możliwe złośliwe oprogramowanie, które szybko zweryfikuje dane. Częstą metodą hakerów jest podszywanie się pod banki z prośbą o weryfikację - i podanie w tym celu hasła ${ }^{14}$.

Inwestorzy giełdowi za pośrednictwem sieci mają możliwość dokonania transakcji kupna i sprzedaży papierów wartościowych, a także tani dostęp do informacji o rynkach i trendach oraz do raportów analiz giełdowych. Umożliwia to łatwiejszy dostęp do grona takich uczestników rynku.

12 K. Cheć, Internet jako narzędzie nowoczesnego marketingu, 20 VI 2012, [online] http://www.gumul$\mathrm{ka} . \mathrm{pl} / \mathrm{cnt}$.spx ?content=548, 28 IX 2012.

13 Polska Internetowa..., s. 25-26.

14 Ł. Latacz, Bezpieczeństwo kont internetowych, 3 IV 2012, [online] http://www.ekonomia.pl/artykuly/ konta-bankowe/konta-osobiste/bezpieczenstwo-kont-internetowych, 29 IX 2012. 
Na płaszczyźnie przedsiębiorstw w tym dziale korzyści płynące z sieci są wykorzystywane przez agencje ubezpieczeniowe. Statystyki pokazują, że do najchętniej wykupowanych usług online należą te związane z użytkowaniem samochodu (OC, Autocasco). Firmy obniżają ceny swoich usług nawet o $30 \%$ z uwagi na to, że mogą zaoszczędzić na dodatkowych kosztach przeznaczonych na wynagrodzenie przedstawiciela. Proponują również opłacanie składki na raty, a nie jednorazowo, lecz należy wtedy pamiętać, że będzie ona droższa. Opis warunków ubezpieczenia, zazwyczaj napisany dość skomplikowanym językiem, warto przeczytać uważnie, a w razie pytań - dzwonić na infolinię danego ubezpieczyciela ${ }^{15}$.

Duży wkład w gałąź finansów mają banki, które już na początku XXI w. odważnie wdrażały w swoje systemy innowacyjne usługi internetowe, pomimo tego, że dostęp do sieci i jej rozpowszechnienie było bardzo niewielkie. Oferowały one atrakcyjne oprocentowanie depozytów, mając nadzieję, że to przyciągnie klientów. Najistotniejszą rolę odegrał wysokooprocentowany rachunek oszczędnościowy dający elastyczną możliwość wpłat i wypłat pieniędzy. Chociaż posiadanie w ofercie prowadzenia rachunku internetowego również ma niebagatelne znaczenie - każdy liczący się bank na rynku umożliwia to klientom. Usługa ta jest równie popularna wśród pojedynczych konsumentów, jak i wśród przedsiębiorstw - w 2010 r. korzystało z niej 1,6 mln małych i średnich firm. Na tych zmianach zyskują zarówno klienci, jak i banki, które obniżają koszty transakcyjne, a przy tym zwiększają rentowność swoich placówek.

W naszym państwie oddziaływanie Internetu na bankowość i finanse kształtuje się na dość wysokim poziomie. Dowodzi tego raport Deutsche Banku, który brał pod uwagę liczbę aktywnych rachunków internetowych w porównaniu do wszystkich rachunków. Polska uzyskała wynik $21 \%$, co oznacza, że jesteśmy jednym z przodujących państw w tej dziedzinie w Europie Wschodniej - w porównaniu do Węgier (16\%) czy Czech $(18 \%)^{16}$. Sukces polskiej bankowości służy jako przykład przeskoczenia zapóźnienia - zamiast iść krok w krok za kolejnymi etapami rozwoju państw zachodnich, pominęliśmy fazę obrotu czekowego, a rozwinęliśmy system bankowości elektronicznej i kart kredytowych.

\section{HANDEL I TRANSPORT}

Niemały procent dochodu z Internetu przynosi także handel i transport - około 8\%. Zakupy elektroniczne $\mathrm{w}$ gospodarstwach domowych wywołały niemałe poruszenie. Polaków skusiły przede wszystkim niskie ceny, oszczędność czasu, możliwość szybkiego porównania cen w różnych sklepach oraz duży wachlarz ofert proponowanych przez e-sklepy, często większy niż w tradycyjnych sklepach. Dzięki Internetowi możli-

15 P. Banaszak, Ubezpieczenie przez Internet, 14 VI 2011, [online] http://www.nbportal.pl/pl/np/porady/poradniki/efinanse/kupujemy-ubezpieczenie-przez-internet, 29 IX 2012.

16 Online banking and research, Deutsche Bank Research, Frankfurt, XI 2010, s. 2, [online] http://www. dbresearch.com/PROD/DBR_INTERNET_EN-PROD/PROD0000000000264269.PDF, 2 VIII 2012. 
we jest znalezienie w krótkim czasie najtańszej i najbardziej odpowiadającej potrzebom klienta oferty. Wartość e-zakupów zrobionych przez obywateli Polski w 2009 r. sięga 1 mld PLN ${ }^{17}$. To, że internauci zaskakująco szybko obdarzyli zaufaniem sklepy internetowe, jest po części zasługą banków budujących bezpieczny system obsługi finansów w sieci.

Oprócz wielu pozytywnych efektów takich usług, znaleźć można te mniej przyjemne, jak chociażby brak możliwości dotknięcia i realnego obejrzenia kupowanego produktu. Zniechęca również czas jego przesyłki do klienta, który może zająć nawet kilka dni. Warto także przed ostateczną decyzją sprawdzić, czy sklep akceptuje zwroty - na wypadek, gdyby artykuł nas nie zadowolił - oraz czy opinie o sprzedawcy są pochlebne.

Dane statystyczne pokazują, że aż 63\% badanych najczęściej sprawdza informacje dotyczące podróży zagranicznych w sieci. Jednak polskie społeczeństwo nie jest jeszcze przekonane do dokonywania takich zakupów przez Internet - dużą rolę odgrywa czynnik ludzki. Najczęściej wyszukujemy miejsca, gdzie moglibyśmy spędzić urlop, ale kiedy przychodzi do sfinalizowania - podpisania umowy i zapłaty za usługę - wolimy zrobić to bezpośrednio w biurze turystycznym. Takie rozwiązanie nazywane jest efektem ROPO (ang. Research Online Purchase Offline); jego wpływ można dostrzec także w innych gałęziach gospodarki ${ }^{18}$. Jeśli chodzi o odpoczynek w granicach naszego kraju, Polacy najczęściej kontaktują się bezpośrednio z usługodawcą. Przy takich wynikach oraz wysokim efekcie ROPO w naszym społeczeństwie zaskakują liczby dotyczące chociażby zakupu biletów lotniczych za pomocą Internetu - stanowią one ponad 50\% takich umów.

Nowe możliwości wprowadziły rewolucję również w przedsiębiorstwach związanych z handlem. Największą popularnością w sieci cieszą się produkty z działu elektronika. Często kupowane są książki, wszelkiego rodzaju multimedia, towary z dziedziny "dom i ogród”, a także odzież i dodatki. Nie wszystkie działalności rozwijały się w odpowiednim tempie - początkowo wiele trudności przysparzało dostarczenie zamówionego produktu do wyznaczonego miejsca o czasie, jednak obecnie 10-20\% rocznych przychodów firm logistycznych pochodzi z dostarczania zakupów internetowych.

Liczba e-sklepów wzrasta z roku na rok - w 2007 r. wynosiła ona 340, a w 2010 r. już 540. Takie zjawisko doprowadza do sytuacji, w której przedsiębiorstwa muszą konkurować ze sobą ceną oraz jakością artykułów. $Z$ tego powodu marże handlowe osiągnęły poziom około $3 \%$, ale przedsiębiorstwa, których przychody zmniejszyły się z tego powodu, rekompensują stratę szybkim przyrostem obrotów.

Uzasadnione wydaje się stwierdzenie, że dostęp do sieci zrewolucjonizował rynek turystyczny - zlikwidował małych pośredników, zmniejszył wydatki na koszt dotarcia informacji do potencjalnych klientów, jest także doskonałym miejscem na promocję usług. Dlatego 90\% firm wliczających się w tę dziedzinę gospodarki posiada swój adres internetowy.

Polska Internetowa, s. 26-27.

18 Efektywna odpowiedź na efekt ROPO w turystyce, Qtravel.pl, 28 VI 2011, [online] http://blog.qtravel. $\mathrm{pl} /$ nowosci-w-qtravel/efektywna-odpowiedz-na-efekt-ropo-w-turystyce, 3 VIII 2012. 
Dzięki rozwijającemu się e-handlowi, sytuacja naszego państwa rozwija się, lecz trzeba przyznać, że powoli i wyjątkowo ostrożnie, jeśli przyrównać ją do sytuacji krajów Europy Zachodniej. Za pomocą sieci szanse na zaistnienie mają mniejsze, polskie ośrodki turystyczne, które przyciągają zagranicznych podróżników spragnionych poznania naszej historii i kultury, co także w dużej mierze oddziałuje na ową sferę rynku.

Przemysł, budownictwo, rolnictwo zajmują jedno z ostatnich miejsc w łącznej wartości dodanej związanej z Internetem - ich udział odzwierciedlony w liczbach to kolejno 4\%, 1\% i 0\%. Jednak w wartości dodanej ogólem udział Internetu w przemyśle wzrasta prawie sześciokrotnie. Dzięki temu możemy stwierdzić, jaką wagę ma dostęp do sieci w poszczególnych sekcjach gospodarki ${ }^{19}$.

\section{DOŚWIADCZENIA INNYCH PAŃSTW}

Nasz kraj znajduje się na przegranej pozycji: importuje komputery i sprzęt telekomunikacyjny, zamiast czerpać dodatkowe dochody z gospodarki internetowej. Przykład powinniśmy brać z sąsiada - Czech, które do sieci został podłączone później niż Polska, a siedziby firm komputerowych znajdują się właśnie w jego granicach. To oddziałuje na pełną wartość PKB, jaką to państwo zyskuje dzięki sieci - 3,6\%, podczas gdy w Polsce wynosi ona $2,7 \%$. Obywatele Czech szybciej przekonali się do rozwijania tego obszaru, pomimo większego opóźnienia. W 2010 r. ponad 65\% populacji stanowili internauci, co oznacza $6,5 \mathrm{mln}$ osób ${ }^{20}$.

Czeska aktywność w sieci nie jest wiele większa niż w Polsce, ale za to w firmach lwie korzyści płynące z Internetu są dość często wykorzystywane - prawie $80 \%$ posługuje się nim do różnych celów, pomimo tego, że infrastruktura internetowa i szybkość łączy pozostawiają wiele do życzenia. Przedsiębiorstwem wyróżniającym się w handlu, o którym warto wspomnieć, jest Avast, jedna z popularnych firm przygotowujących oprogramowanie antywirusowe, stworzona przez Czechów Eduarda Kučera i Pavla Baudiša. W 2002 r. zaoferowała swoją usługę za darmo, a 8 lat później korzystało z niej już 130 mln użytkowników, chociaż zarządzało nią jedynie 150 osób. Kolejnym przykładem jest Miloš Winkler, który w 1997 r. założył pierwszą w tym kraju kwiaciarnię ze stroną internetową. Szybko dostrzegł, jakie korzyści może mu przynieść połączenie z siecią oprócz oferowania usług sprowadza kwiaty z Niemiec, gdzie jest większy wybór i niższe niż u czeskich dostawców ceny ${ }^{21}$.

Wysoko plasują się nasi sąsiedzi, jeśli chodzi o wielkość wydatków konsumentów oraz przedsiębiorstw związanych z siecią w sektorach reklamy bądź handlu. Jednak wi-

19 Wptyw przyspieszonego rozwoju szerokopasmowego dostepu do Internetu..., s. 16.

20 Czech Republic Internet Usage and Telecommunications Report, Internet World Stats, [online] http:// www.internetworldstats.com/eu/cz.htm, 5 VIII 2012.

21 Czech Online. How The Internet is Transforming the Chech Economy, The Boston Consulting Group, III 2011, s. 21-25, [online] http://www.valueoftheweb.com/\#, 6 VIII 2012. 
dać ich nieufność do sektora e-finansów przy zakupach elektronicznych: aż 45\% osób wybiera płatność przy odbiorze przesyłki. Pomimo tego, a także opóźnienia w dostępie do Internetu, aparat państwowy potrafi przekonać obywateli do rozwoju innowacyjnych dziedzin.

Interesująco rysują się państwa Europy Północnej, prężnie rozwijające gospodarkę przy wykorzystaniu dobrodziejstw płynących z sieci. Szwecja, która liczy ponad $8 \mathrm{mln}$ internautów przy niecałych $10 \mathrm{mln}$ obywateli, jest jednym z przodujących w tej dziedzinie krajów na świecie ${ }^{22}$. Jej udział w PKB wynosił w 2009 r. 6,6\%, czyli 40 bln dolarów amerykańskich. Szwedzkie dziedzictwo innowacyjności, pociąg do technologii, otwarte i bardzo dynamiczne społeczeństwo sprzyjają rozrostowi gospodarki internetowej, dzięki której ma zatrudnienie ok. 60 tys. osób.

Według raportu the World Economic Forum z 2011 r., to właśnie w tym kraju są najlepsze możliwości rozwoju nowych technologii oraz innowacji. Zapewnia je fakt, że Szwecja jako pierwsze europejskie państwo została podłączona do szerokopasmowego Internetu. Dzięki temu gospodarka jest oparta na wiedzy, a najnowsze modele biznesowe, produkty oraz serwisy mają szanse na szybkie zaistnienie na rynku i dalszy postęp $^{23}$. Efekty tego można zauważyć w wykorzystywaniu przez małe i średnie przedsiębiorstwa zaawansowanych narzędzi. Przodując we wszystkich dziedzinach związanych z Internetem, pozostałe kraje mogą jedynie czerpać z doświadczeń państwa o najbardziej nowoczesnej gospodarce w Europie.

Liderem w dziedzinach związanych z Internetem są Stany Zjednoczone Ameryki Północnej. Ten kraj, posiadający $310 \mathrm{mln}$ obywateli, z których $77 \%$ to internauci, jest miejscem pierwszych prób połączeń internetowych. W 2010 r. dziedzina ta stanowiła 4,7\% PKB, a więc przewyższała swoją wartością takie sektory, jak edukacja, rolnictwo czy sztuka. Duża rolę w tego typu gospodarce w Stanach Zjednoczonych odgrywa branża reklam prezentujących produkty lub witryny internetowe. Rozpowszechnione jest przesyłanie na elektroniczne skrzynki pocztowe wiadomości o ofertach, które mogą zaciekawić potencjalnego konsumenta; w tym celu wykonuje się analizy ostatnio przeglądanych artykułów na stronie

Aby ułatwić wyszukiwanie najlepszych propozycji na rynku, wprowadzono w Stanach Zjednoczonych aplikację telefoniczną, dzięki której, będąc w sklepie, możemy sprawdzić cenę danego artykułu w sklepach internetowych przez zeskanowanie kodu kreskowego. W ten sposób bez używania komputera klient szybko dokona wyboru najkorzystniejszej oferty. Planowane jest wprowadzenie takiej aplikacji także w Europie w ciągu kilku najbliższych lat.

Dzięki rozpowszechnionym możliwościom użytkowania Internetu pracę ma 1,2 mln obywateli Ameryki - budując strukturę, pracując nad reklamami czy też zajmując się e-handlem. Według raportu the Boston Consulting Group to przedsiębiorstwa

22 Sweden Internet Usage, Population and Telecomunications Report, Internet World Stats, 1 VI 2010, [online] http://www.internetworldstats.com/eu/se.htm, 6 VIII 2012.

23 S. Dutta, I. Mira, The Global Information and Technology Report 2010-2011, Genewa 2011, s. 11, [online] http://www3.weforum.org/docs/WEF_GITR_Report_2011.pdf, 7 VIII 2012. 
oferujące usługę dostępu do sieci zatrudniają największą liczbę ludzi, a także przynoszą największe zyski. Na kolejnych miejscach znaleźli się producenci sprzętu komputerowego (Apple, Hawlett-Packard, Dell), firmy consultingowe (Accenture, IBM) oraz produkujące oprogramowanie (Adobe, Microsoft, McAfee) ${ }^{24}$. Dużą rolę w e-gospodarce odgrywają małe firmy, często jednoosobowe, które handlują produktami na witrynach takich jak Ebay.

Internet stał się jedną z najważniejszych usług dla obywateli Stanów Zjednoczonych. Międzynarodowa firma doradcza The Boston Consulting Group przeprowadziła badania, które miały udzielić odpowiedzi na pytanie o to, jak wysoko znajduje się Internet na liście priorytetów społeczeństwa USA. 77\% badanych stwierdziło, że dla Internetu mogłoby zrezygnować z czekolady, $73 \%$ byłoby w stanie darować sobie alkohol, zaś $21 \% \mathrm{z}$ ankietowanych internautów poświęciłoby swoje życie seksualne ${ }^{25}$.

Stany Zjednoczone są internetową potęgą i wnoszą, dzięki swej innowacyjności, aż 30\% do tej dziedziny w gospodarce światowej. Jednak to Korea Południowa jest od lat 60. XX w. najbardziej dynamicznie rozwijającym się państwem, chociaż przed tym okresem nic nie wskazywało na to, że może osiągnąć tak wysoki poziom postępu. Sytuację zmieniło dojście do władzy Parka Chung-hee, który przedstawił społeczeństwu propozycje poważnych zmian w tym zakresie. W latach 80. skoncentrowano się na przemyśle opartym na nowych technologiach, a w kolejnym dziesięcioleciu - na ich innowacjach ${ }^{26}$.

Zaczęto inwestować w szkolnictwo wyższe i tworzyć new economy, w dużej mierze opartą na wiedzy. Jednym z jej ważniejszych założeń był wzrost wykorzystania łączy szerokopasmowych. Usługa ta dostępna była już w 1998 r.; obecnie w Korei Południowej z Internetu korzysta $82 \%$ obywateli, a połowa z nich ma połączenie $50-100 \mathrm{Mb} / \mathrm{s}^{27}$. Ten krok wykonany przez władze miał decydujące znaczenie dla rosnącego trzy razy szybciej niż inne gałęzie ekonomii sektora ICT (Information and communications technology teleinformatyka), w którym zatrudnienie znajduje 300 tys. Koreańczyków. Rozwija się on głównie dzięki wyszukiwarkom, lokalnym serwisom internetowym oraz grom online, w których koreańskie przedsiębiorstwa są liderem na rynkach światowych.

Wiele inicjatyw wyszło ze strony rządu, który starał się przybliżyć ludziom możliwości, jakie daje dostęp do sieci. W 2000 r. ogłoszono program Internetowej Edukacji, z którego skorzystało $10 \mathrm{mln}$ osób. Aby rozwinąć sektor prywatny, zachęcano do inwestycji w infrastrukturę oraz rozwój popularności Internetu, co w latach 1995-2005 osiągnęło sumę 32 mld dolarów. Dzięki temu konkurencja pomiędzy przedsiębiorstwami wzrosła.

24 Economic Value of the Advertising - Supported Internet Ecosystem, Hamilton Consultants, Cambridge Massachusetts, 10 VI 2009, [online] http://www.valueoftheweb.com/\#, 7 VIII 2012.

25 C. Palis, Internet Economy: How Essential Is The Internet to the U.S.?, 20 III 2012, [online] http://www. huffingtonpost.com/2012/03/20/internet-economy-infographic_n_1363592.html, 8 VIII 2012.

26 Gospodarka Republiki Korei, Ambasada Rzeczpospolitej Polskiej w Seulu, 4 VIII 2010, [online] http:// www.seoul.trade.gov.pl/pl/korea/article/detail,134,Gospodarka_Republiki_Korei.html, 8 VIII 2012.

27 Asia Marketing Research, Internet Usage, Population Statistics and Facebook Information, Internet World Stats, 31 XII 2011, [online] http://www.internetworldstats.com/asia.htm, 9 VIII 2012. 
E-gospodarki przedstawionych powyżej państw znajdują się na różnych etapach rozwoju. W każdej z nich jest coś specyficznego, w każdej jakaś sfera tej dziedziny się wyróżnia. W Czechach jest to dość szeroko rozbudowany sektor małych i średnich przedsiębiorstw, które rozwijają się dzięki korzyściom płynącym z dostępu do sieci. Szwecja jest charakterystyczna ze względu na dynamiczne społeczeństwo, z kolei Stany Zjednoczone posiadają na swoim terytorium wielkie przedsiębiorstwa, takie jak Microsoft czy Apple, tworzące do 30\% światowych zysków z udziału Internetu w gospodarce. Pracowite społeczeństwo i rozważne decyzje bez pustych słów to cechy wyróżniające Koreę Południową. W Polsce obywatelom trudno uwierzyć, że plany szerokiej informatyzacji, przedstawiane podczas kolejnych kampanii wyborczych, zostaną rzeczywiście zrealizowane i wpłyną pozytywnie na stan gospodarki. $Z$ drugiej strony naszym biznesmenom brak umiejętności wykorzystywania innowacji technologicznych i przenoszenia ich na efekty gospodarcze ${ }^{28}$.

\section{POLSKIE PRÓBY REFORM}

Późne dostrzeżenie problemu, jakim jest słaba informatyzacja kraju, objawiło się utworzeniem Ministerstwa Administracji i Cyfryzacji w listopadzie 2011 r. po przekształceniu Ministerstwa Spraw Wewnętrznych i Administracji oraz Ministerstwa Infrastruktury. Na jego czele stanął Michał Boni - jeden z najbardziej zaufanych współpracowników Donalda Tuska. Resort ten przejął sprawy z zakresu systemów i sieci teleinformatycznych administracji publicznej, szeroko rozumianej technologii, wspierania inwestycji w tej dziedzinie oraz rozwoju społeczeństwa informacyjnego ${ }^{29}$. Początkowo pojawiało się wiele głosów, szczególnie z partii opozycyjnych, na temat utworzenia nowego ministerstwa - widziano w nim jedynie możliwość nobilitacji Michała Boniego. Kontrargument głosił, że jedynie osoba o silnej pozycji politycznej mogła zapewnić sprawne funkcjonowanie tego resortu ${ }^{30}$.

W XXI w. rola Internetu i jego wpływ na polską gospodarkę dynamicznie rosną. Dotychczasowe doświadczenia wskazują, że zarówno urzędnicy, jak i obywatele niełatwo przyswajają związane z tym innowacje. Dzieje się to pomimo dążeń państwa do ułatwienia tego rodzaju procesów ${ }^{31}$.

W potocznie zwanym e-government chodzi o ciągłe doskonalenie jakości usług. Relacje zewnętrzne, czyli te zachodzące między urzędem a obywatelem, i wewnętrzne,

28 U. Smuktunowicz, Jak Internet wptywa na gospodarkę, 5 VII 2011, [online] http://www.crn.pl/artykuly/raporty-i-analizy/2011/06/jak-internet-wplywa-na-gospodarke, 9 VIII 2012.

29 http://mac.gov.pl/administracja-i-samorzad/

30 J. Itrich-Draberek, Koncepcja powstania Ministerstwa Administracji i Cyfryzacji, 30 XI 2011, [online] http://oapuw.pl/index.php?option $=$ com_content\&view $=$ article\&id=279\%3Akoncepcja-powstania-ministerstwa-administracji-i-cyfryzacji-opinia-ekspertow-oap-uw\&catid=159\%3Aopinie $\&$ Itemid=67\&lang=pl, 30 VIII 2012.

31 A. Baranowska-Skimina, E-administracja w Polsce:perspektywy rozwoju, 3 V 2011, [online] http://www. egospodarka.pl/65112,E-administracja-w-Polsce-perspektywy-rozwoju,4,39,1.html, 30 VIII 2012. 
pomiędzy urzędami, ulegają przekształceniu. Przede wszystkim można zaobserwować nacisk na oszczędność jednej z ważniejszych wartości XXI w. - czasu. Kolejnym efektem e-administracji ma być oszczędność kapitału obywateli, urzędników i przedsiębiorców, zwiększanie zakresu informacji i klarowności procedur.

Pierwszy projekt MAiC dotyczył podnoszenia kompetencji i wymiany doświadczeń polskiej kadry teleinformatyki. Aby sprawnie funkcjonowały urzędy, pracownicy powinni być na bieżąco z nowościami technologicznymi. Co więcej, dzielenie się doświadczeniami, projektami oraz przedsięwzięciami należy traktować jako próbę zbliżenia różnych działów administracji, co powinno skutkować zwiększeniem efektywności polskiej biurokracji.

Szeroko zakrojony jest projekt Elektronicznej Platformy Usług Administracji Publicznej, który pozwala na załatwienie wielu spraw urzędowych związanych z edukacją, zdrowiem, podatkami, nieruchomościami, kartografią, kulturą czy nawet dofinansowaniami z funduszy Unii Europejskiej za pośrednictwem Internetu. System umożliwia składanie wielu wniosków i pism, pomaga również w komunikacji między urzędami ${ }^{32}$. Widać powolne zmiany spowodowane cyfryzacją. Powszechne i nagłośnione przez media w ostatnim roku stało się składanie elektronicznej deklaracji podatkowej. Co roku odnotowywany jest wzrost liczby osób wykorzystujących tę opcję - w 2010 r. zrobiło to 3,4 mln podatników. Jednak takie usługi jak składanie pozwów cywilnych w ramach e-Sądu czy korzystanie z elektronicznej platformy administracji publicznej wciąż nie budzą zaufania wielu użytkowników. Projekt znajduje się obecnie na wczesnym etapie rozwoju: nie wszystkie placówki zapewniają całościową dostępność usług online, a zdarzają się nawet takie, które obsługi elektronicznej nie zapewniają w ogóle.

Bezpieczeństwo obywateli pozostaje jednym z priorytetów państwa narodowego. Także w tym zakresie można zaobserwować zwiększające się znaczenie Internetu. W Polsce przejawia się to chociażby w procesie usprawniania usługi uniwersalnego numeru ratunkowego: 112. Niezbędne staje się stworzenie systemu teleinformatycznego, czyli tzw. Systemu Informatycznego Powiadamiania Ratunkowego, który ma zwiększyć efektywność i skuteczność działania tego numeru oraz integracji służb niosących pomoc.

Jednym z najbardziej znaczących projektów, ale zarazem najtrudniejszych do wykonania, jest Narodowy Plan Szerokopasmowy, który zakłada, że w 2013 r. dostęp do sieci będzie powszechny, zaś w 2020 r. wszyscy Polacy mają posiadać łącze internetowe o prędkości przekraczającej $30 \mathrm{Mbit} / \mathrm{s}$, natomiast co drugie gospodarstwo domowe - o przepustowości $100 \mathrm{Mbit} / \mathrm{s}$. Są to wytyczne Europejskiej Agendy Cyfrowej, do których państwa członkowskie Unii Europejskiej powinny się zastosować i zaplanować rozwój łączy szerokopasmowych ${ }^{33}$.

32 S. Wikariak, ePUAP - tu zatatwisz sprawy urzędowe przez Internet, 22 IX 2011, [online] http://prawo.rp.pl/artykul/720787.html, 30 VIII 2012.

33 Komunikat Komisji do Parlamentu Europejskiego, Rady, Europejskiego Komitetu Ekonomiczno-Spotecznego i Komitetu Regionów, Europejska Agenda Cyfrowa, Bruksela, 26 VIII 2010, s. 24, [online] http://eur-lex.europa.eu/LexUriServ/LexUriServ.do?uri=COM:2010:0245:FIN:PL:PDF, 1 IX 2012. 
Początkowo Ministerstwo Administracji i Cyfryzacji chce zdefiniować obszary o najniższych wskaźnikach dostępu oraz określić, jakie narzędzia będą pomocne w dokonaniu przełomu. Stwierdzono również, że znaczącą rolę może odegrać porozumienie między przedstawicielami sektora telekomunikacyjnego, rządu oraz samorządów województw. W tym celu w grudniu 2011 r. podpisano memorandum w sprawie współpracy na rzecz budowy i rozwoju sieci szerokopasmowych, bez których gospodarka Polski nie będzie rozwijać się w takim samym tempie, jak pozostałe państwa europejskie ${ }^{34}$.

\section{KU SPOŁECZEŃSTWU INFORMACYJNEMU?}

Za zmianami zachodzącymi w ekonomii państwa idą także przekształcenia między obywatelami, co prowadzi do powstania społeczeństwa informacyjnego. W tej dziedzinie także realizowanych jest kilka projektów. Jeden z nich to Kongres Wolności w Internecie, który zaistniał po zdarzeniach związanych z ACTA. Jego zadaniem jest sformułowanie Karty Praw Podstawowych w Internecie określającej granice ingerencji władz publicznych oraz sugerowanie zmian w prawie ${ }^{35}$. Kolejne spotkania podczas Kongresów Wolności przynoszą wypracowane w grupach warsztatowych plany działania, według których krok po kroku mają ruszać modyfikacje.

Otwarte zasoby cyfrowe to kolejny program wspomagający rozwój. Jego założeniem jest rozpowszechnienie informacji publicznej i zasobów wiedzy, co powinno znaleźć odzwierciedlenie w ewolucji innowacyjnego społeczeństwa i gospodarki. Młode pokolenie Polaków potrafi bez problemu wyszukiwać wiadomości w sieci, ale duża liczba starszych ludzi wciąż nie potrafi tego zrobić, a na tym najbardziej cierpi gospodarka i oni sami. Aby przyśpieszyć ten proces, realizowany jest projekt Latarnicy Polskiej Cyfryzacji, polegający na zatrudnieniu „przewodników” po interaktywnym świecie dla osób powyżej 50. roku życia.

Ministerstwo Administracji i Cyfryzacji oraz Ministerstwo Edukacji Narodowej przyczyniły się do wprowadzenia od 1 września 2012 r. pilotażu rządowego programu "Cyfrowa Szkoła", który będzie przeprowadzony w 380 publicznych szkołach podstawowych w klasach IV-VI. Pierwszy punkt programu dotyczył uzupełnienia braków sprzętowych. Według obu resortów w dłuższej perspektywie ma nastąpić przełom w kreatywnym myśleniu i przygotowywaniu młodych Polaków do życia w cyfrowym świecie. Pozwoli im to na lepsze przystosowanie się do przyszłej sytuacji na rynku pracy, znajdzie też zapewne istotne odzwierciedlenie w stopie rozwoju ekonomicznego państwa.

34 Samorzadowcy, firmy i MAC razem o szerokopasmowym Internecie, Ministerstwo Administracji i Cyfryzacji, 21 XII 2011, [online] http://mac.gov.pl/wiadomosci/samorzadowcy-firmy-i-mac-o-szerokopasmowym-internecie/, 1 IX 2012.

35 Internet będzie wolny. Boni obiecuje internautom, $22 \mathrm{~V}$ 2012, [online] http://polska.newsweek.pl/ internet-bedzie-wolny-boni-obiecuje-internautom,89130,1,1.html, 1 IX 2012. 


\section{PODSUMOWANIE}

Polska gospodarka internetowa odnotowuje od kilku lat stały wzrost, a przewidywania na przyszłość wypadają pozytywnie. W 2015 r. ma ona osiągnąć 4,1\% wielkości PKB przy najbardziej pesymistycznym założeniu. Według wariantu optymistycznego zbliży się do 5\%. Spodziewane jest, że główną siłą napędową tego procesu będzie e-handel, a w tym wydatki konsumenckie z zakupów online elektroniki, multimediów i kosmetyków $^{36}$. Rozpowszechnienie Internetu ma sięgnąć $75 \%$, do czego znacząco przyczyni się popularność smartfonów, a co się z tym łączy - mobilnego dostępu do sieci. Następnie przewidywany jest wzrost liczby inwestycji, jakie przedsiębiorstwa będą wiązać z nowym medium - oprogramowaniami dla firm nietelekomunikacyjnych oraz niezbędnymi innowacjami dla firm telekomunikacyjnych.

$\mathrm{Na}$ tle pozostałych krajów obywatele Polski ciągle zbyt mało wiedzą na temat Internetu i tego, ile korzyści - od osobistych, aż po rozbudowę gospodarki całego państwa - można z niego czerpać. Stagnacja społeczeństwa, które nie ma wewnętrznej potrzeby, aby szybko się rozwijać czy poznawać nowinki technologiczne, to jeden z prawdopodobnych powodów takiego stanu rzeczy.

Internet otwiera furtki niemalże w każdej dziedzinie, przyczynia się do rozwoju społeczno-gospodarczego, tworzy przestrzeń, której granice wciąż się poszerzają, wpływając na rynki globalne. To powinno być motorem do wprowadzania nowych technologii w polskich przedsiębiorstwach. Co prawda w 2007 r. dostęp do Internetu posiadato aż $92 \%$ z 3,5 mln firm, ale wykorzystywano go jedynie do wyszukiwania informacji ${ }^{37}$. Głównym problemem jest brak wiedzy na temat handlu elektronicznego, sposobów działania oraz oceny ryzyka. Polscy przedsiębiorcy nie potrafią w pełni wykorzystać perspektyw, jakie daje im rozwój nowych technologii, do rozbudowy swoich firm, a tym samym wzmocnienia całej gospodarki.

Według autorów raportu „Polska 2030 - Trzecia fala nowoczesności” kraj powinien się w najbliższych latach mocno oprzeć o trzy filary. Pierwszy to innowacyjność, której podstawą powinien być kapitał intelektualny oraz wykorzystanie zdobyczy cywilizacji w uzyskaniu konkurencyjności naszego kraju z innymi państwami. Równowaga w różnicach terytorialnych to kolejny filar. Ostatni - to skuteczność związana z działalnością organów państwowych oraz klarownością decyzji, która powinna sprawić, że uczynią je przyjaznymi dla obywateli ${ }^{38}$. Ale aby te podpory rozwoju zaistniały, musiałyby zostać podjęte zdecydowane kroki ze strony państwa. Niestety, to, co jest w tym kierunku czy-

36 Polska Internetowa..., s. 37-39.

37 W. Pawlak, Internet - nowa era rozwoju, artykut wicepremiera, ministra gospodarki Waldemara Pawlaka dla Rzeczypospolitej w zwiazku z konferencja OECD w Seulu na temat przysztości Internetu, 4 I 2010, [online] http://www.mg.gov.pl/Serwis\%20Prasowy/Wywiady/Waldemar\%20Pawlak/Internet\%20 nowa\%20era\%20rozwoju.htm, 4 VIII 2012.

38 Polska 2030 - Trzecia fala nowoczesności, Zespół Doradców Strategicznych premiera, 17 XI 2011, [online] http://zds.kprm.gov.pl/sites/default/files/dsrk_1_tom_17_listopada_2011_0.pdf, 5 VIII 2012. 
nione, to wciąż zdecydowanie za mało. Uświadomienie społeczeństwu (także przy użyciu przykładów zagranicznych), jak wielką wartość dla gospodarki może mieć dostęp do sieci i dynamiczne korzystanie z jej dobrodziejstw, ile miejsc pracy prawdopodobnie zostanie stworzonych, a także ile małych i średnich firm przypuszczalnie zacznie dzięki temu lepiej funkcjonować, wydaje się jednym z najważniejszych działań stojących przed MAiC.

\section{BIBLIOGRAFIA}

I. Publikacje książkowe

Literatura pomocnicza

- Monografie i opracowania:

Czapiewski E., Tyszkiewicz J., Historia Powszechna. Wiek XX, Warszawa 2010.

Karciarz M., Dutko M., Informacja w Internecie, Warszawa 2010.

Niedźwiedziński M., Globalny handel elektroniczny, Warszawa 2004.

\section{Publikacje elektroniczne:}

Literatura źródłowa:

Pawlak W., Internet - nowa era rozwoju, artykut wicepremiera, ministra gospodarki Waldemara Pawlaka dla Rzeczypospolitej w zwiazku z konferencja OECD w Seulu na temat przysztości Internetu, 4 I 2010, [online] http://www.mg.gov.pl/Serwis\%20Prasowy/Wywiady/ Waldemar\%20Pawlak/Internet\%20nowa\%20era\%20rozwoju.htm.

Polska 2030 - Trzecia fala nowoczesności, Zespół Doradców Strategicznych premiera, 17 XI 2011 , [online] http://zds.kprm.gov.pl/sites/default/files/dsrk_1_tom_17_listopada_2011_0.pdf. Komunikat Komisji do Parlamentu Europejskiego, Rady, Europejskiego Komitetu Ekonomiczno-Spotecznego i Komitetu Regionów, Europejska Agenda Cyfrowa, Bruksela, 26 VIII 2010, [online] http://eur-lex.europa.eu/LexUriServ/LexUriServ.do?uri=COM:2010:0245:FIN: PL:PDF.

\section{Literatura pomocnicza:}

- Artykuły w czasopismach naukowych:

Pawłowska-Mielech J., Rola i znaczenie Internetu w komunikacji spotecznej, II 2006, [online] http://www.sceno.edu.pl/konferencja/1_5.pdf.

- Artykuły prasowe:

Banaszak P., Ubezpieczenie przez Internet, 14 VI 2011, [online] http://www.nbportal.pl/pl/np/ porady/poradniki/efinanse/kupujemy-ubezpieczenie-przez-internet.

Baranowska-Skimina A., E-administracja w Polsce:perspektywy rozwoju, 3 V 2011, [online] http:// www.egospodarka.pl/65112,E-administracja-w-Polsce-perspektywy-rozwoju,4,39,1.html.

Brzozowski A., Gazety upadaja, bo dziennikarze wybrali internet?, 30 XII 2011, [online] http://cyfropolis.blogspot.com/2012/01/gazety-upadaja-dziennikarze-wybrali.html\#. UGmKH66xeW4.

Cheć K., Internet jako narzędzie nowoczesnego marketingu, 20 VI 2012, [online] http://www. gumulka.pl/cnt.spx? content $=548$. 
Efektywna odpowiedź na efekt ROPO w turystyce, Qtravel.pl, 28 VI 2011, [online] http://blog. qtravel.pl/nowosci-w-qtravel/efektywna-odpowiedz-na-efekt-ropo-w-turystyce.

Internet będzie wolny. Boni obiecuje internautom, 22 V 2012, [online] http://polska.newsweek. $\mathrm{pl} /$ internet-bedzie-wolny-boni-obiecuje-internautom,89130,1,1.html.

Latacz E., Bezpieczeństwo kont internetowych, 3 IV 2012, [online] http://www.ekonomia.pl/ artykuly/konta-bankowe/konta-osobiste/bezpieczenstwo-kont-internetowych.

Malik A., Prawdziwy poczatek Internetu w Polsce - sensacyjne odkrycie, 7V 2011, [online] http:// www.komputerswiat.pl/nowosci/wydarzenia/2011/40/prawdziwy-poczatek-internetu-w-polsce--nieznany-fakt.aspx.

Palis C., Internet Economy: How Essential Is The Internet to the U.S.?, 20 III 2012, [online] http://www.huffingtonpost.com/2012/03/20/internet-economy-infographic_n_ 1363592.html.

Smuktunowicz U., Jak Internet wptywa na gospodarke, 5 VII 2011, [online] http://www.crn.pl/ artykuly/raporty-i-analizy/2011/06/jak-internet-wplywa-na-gospodarke.

\section{- Prace zbiorowe:}

Asia Marketing Research, Internet Usage, Population Statistics and Facebook Infromation, Internet World Stats, 31 XII 2011, [online] http://www.internetworldstats.com/asia.htm.

Czech Online. How The Internet is Transforming the Chech Economy, The Boston Consulting Group, III 2011, [online] http://www.valueoftheweb.com.

Czech Republic Internet Usage and Telecomunications Report, Internet World Stats, [online] http://www.internetworldstats.com/eu/cz.htm.

Dutta S., Mira I., The Global Information and Technology Report 2010-2011, Geneva 2011, [online] http://www3.weforum.org/docs/WEF_GITR_Report_2011.pdf.

Economic Value of the Advertising - Supported Internet Ecosystem, Hamilton Consultants, Cambridge Massachusetts, 10 VI 2009, [online] http://www.valueoftheweb.com/.

European Union Internet Users, Internet World Stats Usage and Population Statistics, 31 III 2012, [online] http://www.internetworldstats.com/europa.htm\#pl.

Gospodarka Republiki Korei, Ambasada Rzeczpospolitej Polskiej w Seulu, 4 VIII 2010, [online] http://www.seoul.trade.gov.pl/pl/korea/article/detail,134,Gospodarka_Republiki_Korei. html.

Heylighen F., Complexity and Information Overload in Society: why increasing efficiency leads to decreasing control, 12 IV 2002, [online] http://pespmc1.vub.ac.be/Papers/Info- Overload.pdf.

Itrich-Draberek J., Koncepcja powstania Ministerstwa Administracji i Cyfryzacji, 30 XI 2011, [online] http://oapuw.pl/index.php?option=com_content\&view=article\&id=279\%3Akoncepcja-powstania-ministerstwa-administracji-i-cyfryzacji-opinia-ekspertow-oap-uw\&catid $=159 \% 3$ Aopinie\&Itemid $=67 \&$ lang $=\mathrm{pl}$.

Online banking and research, Deutsche Bank Research, Frankfurt, XI 2010, [online] http://www. dbresearch.com/PROD/DBR_INTERNET_EN-PROD/PROD0000000000264269.PDF.

Polska Internetowa. Jak Internet dokonuje transformacji polskiej gospodarki, The Boston Consulting Group, V 2011, [online] http://polskainternetowa.pl/pdf/raport_BCG_polska_internetowa.pdf. 
Samorzadowcy, firmy i MAC razem o szerokopasmowym Internecie, Ministerstwo Administracji i Cyfryzacji, 21 XII 2011, [online] http://mac.gov.pl/wiadomosci/samorzadowcy-firmy-i-mac-o-szerokopasmowym-internecie.

Sweden Internet Usage, Population and Telecomunications Report, Internet World Stats, 1 VI 2010, [online] http://www.internetworldstats.com/eu/se.htm.

Wikariak S., ePUAP - tu zatatwisz sprawy urzędowe przez Internet, 22 IX 2011, [online] http:// prawo.rp.pl/artykul/720787.html.

Wptyw przyspieszonego rozwoju szerokopasmowego dostępu do Internetu na polska gospodarkęraport, Deloitte, Warszawa 2012, [online] http://www.deloitte.com/assets/Dcom-Poland/ Local\%20Assets/Documents/Raporty,\%20badania,\%20rankingi/pl_szerokopasmowy_internet_raport_lipiec_2012.pdf.

\section{Strony internetowe:}

http://mac.gov.pl/administracja-i-samorzad

Marta SZMAGIER, studiuje stosunki międzynarodowe na Uniwersytecie Jagiellońskim (rok II studiów I stopnia). 